\title{
Polymers as carriers for rhizobial inoculant formulations
}

\author{
Paulo Ivan Fernandes Júnior ${ }^{(1)}$, Tiago Gusmão Rohr ${ }^{(2)}$, Paulo Jansen de Oliveira(2), Gustavo Ribeiro Xavier ${ }^{(3)}$ \\ and Norma Gouvêa Rumjanek ${ }^{(3)}$
}

(1)Universidade Federal Rural do Rio de Janeiro (UFRRJ), Instituto de Agronomia, Departamento de Ciência do Solo, BR 465, Km 7 , CEP 23890-000 Seropédica, RJ, Brazil. E-mail: pauloivanjr@gmail.com (2)UFRRJ, Instituto de Tecnologia, Departamento de Engenharia Química. E-mail: tiagorohr@bol.com.br, pjansen@ufrrj.br ${ }^{(3)}$ Embrapa Agrobiologia, BR 465, Km 7, CEP 23890-000 Seropédica, RJ, Brazil. E-mail: gustavo@cnpab.embrapa.br, norma@cnpab.embrapa.br.

\begin{abstract}
The aim of this work was to evaluate the efficiency of carboxymethyl cellulose (CMC) and starch blends as carrier materials of rhizobial inoculants regarding their capacity to maintain viable cells and promote cowpea (Vigna unguiculata) nodulation. The experimental design adopted was completely randomized, with three replicates. Forty different compositions of carboxymethyl cellulose (CMC) with starch, compatibilized or not with different proportions of $\mathrm{MgO}$ or $\mathrm{ZnO}$, were evaluated regarding their ability of maintaining rhizobial viable cells during the storage period of one month at room temperature, in an initial screening. Thereafter, selected inoculant carrier blends were evaluated regarding their ability to maintain viable rhizobial cells for a period of 165 days, and their performance as inoculant carriers was compared to a peat-based inoculant carrier under greenhouse conditions. Rhizobial cells were better maintained in blends containing $50-60 \%$ CMC. Compatibilizing agents did not increase survival of rhizobial cells for 30 days of storage. The cowpea nodulation of polymer blends was statistically the same of peat-based inoculants. CMC/starch polymer blends are efficient carriers to rhizobial inoculants for up to 165 days of storage, when compatibilized with $\mathrm{MgO}$ $(1 \%)$.
\end{abstract}

Index terms: Bradyrhizobium japonicum, Vigna unguiculata, biological nitrogen fixation, carboxymethyl cellulose, inoculant technology, polymer blends.

\section{Polímeros como veículos para formulações de inoculantes rizobianos}

Resumo - O objetivo deste trabalho foi avaliar a eficiência de misturas poliméricas de carboximetilcelulose (CMC) e amido, como veículos de inoculante para rizóbios, quanto à sua capacidade de manter células rizobianas viáveis e promover a nodulação em feijão-caupi (Vigna unguiculata). O delineamento experimental foi completamente casualizado, com três repetições. Quarenta diferentes composições poliméricas de carboximetilcelulose $(\mathrm{CMC})$ e amido, compatibilizadas ou não com proporções de $\mathrm{MgO}$ ou $\mathrm{ZnO}$, foram inicialmente avaliadas quanto à sua capacidade de manter células rizobianas viáveis pelo período de um mês. Posteriormente, veículos de inoculantes selecionados foram avaliados quanto à capacidade de manter células rizobianas viáveis pelo período de 165 dias, e seu desempenho como veículos de inoculantes foi comparado com os de inoculantes turfosos, em casa de vegetação. Células rizobianas sobreviveram melhor em misturas com 50-60\% de CMC. Os agentes compatibilizantes não aumentaram a sobrevivência das células rizobianas após 30 dias de estocagem. A nodulação do feijão-caupi com o uso das misturas poliméricas não diferiu estatisticamente da nodulação com o uso da turfa. As misturas de CMC/amido, quando compatibilizadas com $\mathrm{MgO}(1 \%)$, são veículos eficientes para inoculantes rizobianos por até 165 dias de armazenamento.

Termos para indexação: Bradyrhizobium japonicum, Vigna unguiculata, fixação biológica de nitrogênio, carboximetilcelulose, tecnologia de inoculantes, misturas poliméricas.

\section{Introduction}

Biological nitrogen fixation (BNF) occurs in several legume plants due to symbiosis with soil rhizobia. Grain legumes, such as soybean, cowpea, common bean and peanut are able to establish associations with different rhizobial species (Hara \& Oliveira, 2005). These associations have an important environmental and social role, once the exploitation of BNF in agriculture reduces the use of mineral nitrogen fertilizers, which have high costs and present some environmental risks as lixiviation and eutrophication of water resources (Ben Rebah et al., 2007).

Farmers make use of this legume-rhizobia interaction by applying rhizobial inoculants to seed grain or to soil (Lupwayi et al., 2006). Commercial rhizobial 
inoculants have been used for over a century to obtain higher crop yields. It has been estimated that some 2,000 tons of rhizobial inoculants are produced worldwide every year (Ben Rebah et al., 2007).

Rhizobial inoculants are available in several formulations: granular inoculants are distributed over the soil after sowing, and high quantities are necessary for an efficient inoculation in this case (Lupwayi et al., 2006); liquid inoculants are commonly used in large areas, mainly with soybean, in South America (Freire \& Vernetti, 1999), since liquid carrier inoculants are better suited for mechanical sowing; peat inoculants are sold in Brazil since the 1950s (Freire \& Vernetti, 1999) and, nowadays, account for half of the inoculant market in Brazil. The use of peat inoculants is also restricted due to variations in the chemical and physical properties. Moreover, peat is a material of fossil origin from a nonrenewable resource, extracted from a very fragile natural system, the peat bogs.

In order to increase the inoculant quality and efficiency, and to reduce costs and environmental impacts, alternative carriermaterials have been studied (Ben Rebah et al., 2007; Albareda et al., 2008), including single and composite polymer formulations (Dommergues et al., 1979; Jawson et al., 1989; Denardin \& Freire, 2000; Schuh, 2005; Deaker et al., 2007), which have already been evaluated as rhizobial carriers (Dommergues et al., 1979; Denardin \& Freire, 2000; Sarr et al., 2005), and associative bacteria (Bashan \& Gonzales, 1999).

Starch is a mixture of amylopectin (at about 75\%) and amylose (at about 25\%), directly extracted from plant material such as corn and wheat grains (Parker \& Ring, 2001). Carboxymethyl cellulose (CMC) is a cellulose-derived ester, originated by the reaction of cellulose with sodium hydroxide and with sodium monochloroacetate, which results in a long chain of anhydroglucose which in turn generates a highly hygroscopic and viscous polymer, nontoxic to humans (Sanz et al, 2005). Starch and CMC are immiscible due to the high molecular weight of both. Nevertheless, their molecular similarity results in a partial affinity and contributes to the stability of the formed gel (Suvorova et al., 1999), with appropriate rheological and chemical characteristics for rhizobial storage.

The use of compounds, suited for further compatibilization of the $\mathrm{CMC}$ and starch blend, allows an improvement of gel features, such as higher viscosity and hygroscopicity (Rohr, 2007). Furthermore, an advantage of CMC and starch blend, as inoculant carrier material, is that they are cheap and already used in other industrial areas, such as in food and pharmaceutical industries.

The purpose of this study was to evaluate the efficiency of $\mathrm{CMC} /$ starch blends as carrier materials, in new formulations of rhizobial inoculants, regarding their capacity to maintain viable cells and promote cowpea (Vigna unguiculata) nodulation.

\section{Materials and Methods}

The rhizobia strain BR 3267 of Bradyrhizobium japonicum (Martins et al., 2003) was obtained from the diazotrophic culture collection of Embrapa Agrobiologia. The strain BR 3267 was grown in 250-mL flasks containing $100 \mathrm{~mL}$ of yeast extract mannitol (YEM) medium (Vincent, 1970) on a rotary shaker at constant rotation (150 rpm) at $28^{\circ} \mathrm{C}$.

Polymer-based carriers used here were prepared according to a methodology developed by the Laboratório de Tecnologia e Ciência dos Polímeros, at the Instituto de Tecnologia, of Universidade Federal Rural do Rio de Janeiro, Seropédica, RJ, Brazil. The following proportions of $1.28 \% \mathrm{w} / \mathrm{w}$ carboxymethyl cellulose (viscosity 2,000-3,000 cP, Quimesp Ltda., Guarulhos, SP, Brazil) and soluble starch (Vetec Química Fina Ltda., Duque de Caxias, RJ, Brazil) were used: M1, 20-80\%; M2, 40-60\%; M3, 50-50\%; M4, 60-40\%; and M5, 80-20\%. These polymer blends were tested without compatibilization, or with compatibilization by applying $1.0,1.5$ and $2.5 \%$ of the polymer weight of zinc or magnesium oxide, totaling 40 different compositions. To prepare these compositions, the reagents and the right water proportion were blended, and $5 \mathrm{~mL}$ of the blends were transferred to trial tubes and autoclaved.

Bacterial broth was centrifuged at $10,000 \mathrm{~g}$ for $10 \mathrm{~min}$. The supernatant was discarded, and the pellet resuspended in $25 \mathrm{~mL}$ of sterile distilled water. Two milliliters of rhizobial cell suspension were filled into the sterilized polymer blend tubes, resulting in a concentration of $4.5 \times 10^{8}$ cells mL $\mathrm{mL}^{-1}$ for one experiment using $\mathrm{ZnO}$ as compatibilizing agent, and $4.2 \times 10^{8}$ cells mL $\mathrm{mL}^{-1}$ for other experiment using $\mathrm{MgO}$ as compatibilizing agent. The inoculants were stored at room temperature $\left(20-26^{\circ} \mathrm{C}\right)$.

Two samples were taken from each treatment, in order to evaluate the number of viable rhizobial cells by the drop plate method (Miles \& Misra, 1938), in yeast extract manitol agar (YMA) solid medium; the results represent the mean of the two counts. Bacterial counts were carried 
out 1 and 30 days after inoculation (DAI) of the two independent samples. The ANOVA and the Scott-Knott test were performed, at $5 \%$ probability, using the Sisvar software (Universidade Federal de Lavras, Lavras, MG, Brazil).

Based on the above experimental results, $\mathrm{CMC} /$ starch blends were prepared as two compositions, M3 and M4, and were compatibilized or not with $1 \% \mathrm{ZnO}$ or $\mathrm{MgO}$. The rhizobial strain, bacterial growth and inoculant preparation were the same as described above. For this trial, $15 \mathrm{~mL}$ of two compositions of CMC/starch blends were autoclaved in 50-mL Falcon tubes. Peat-based carriers were used as control and prepared by filling $15 \mathrm{~g}$ of milled and sieved peat into polypropylene plastic bags, which were closed and autoclaved. After adding rhizobia to the different carriers, the final cell concentration in the experiment exceeded $1 \times 10^{9}$ cells $\mathrm{mL}^{-1}$ or $\mathrm{g}^{-1}$ of the inoculant. Rhizobial survival was evaluated at $7,13,20$, $26,35,41,54,70,82,103,126,146$ and 165 days of storage through the drop plate method (Milles \& Misra, 1938). The polymer-based inoculants were stored at room temperature, while the peat-based inoculants were cold-stored at approximately $10^{\circ} \mathrm{C}$. The experiment had a completely randomized design with three replicates. The analyses of regression were done, and the significance of equation coefficients was determined using the Sisvar software.

To evaluate the efficiency of inoculants in glasshouse conditions, inoculants were prepared with $\mathrm{M} 3$ and $\mathrm{M} 4$, and compatibilized or not with $1 \% \mathrm{ZnO}$ or $\mathrm{MgO}$; and the experiment was planted only 15 days after the preparation. Soil samples were obtained from five subsamples collected in an A horizon of a sandy Planosol, in an area of the Integrated System of Organic Production (SIPA) of Embrapa Agrobiologia. The nonsterile soil samples were stored in 3-kg pots, previously analyzed as follows (Claessen et al., 1997): $\mathrm{pH}, 5.8 ; \mathrm{N}, 0.49 \mathrm{mg} \mathrm{kg}^{-1}$; $\mathrm{Al}^{+3}, 0.0 \mathrm{cmol}_{\mathrm{c}} \mathrm{kg}^{-1} ; \mathrm{Ca}^{+2}+\mathrm{Mg}^{+2}, 2.1 \mathrm{cmol}_{\mathrm{c}} \mathrm{kg}^{-1} ; \mathrm{Ca}^{+2}$, $1.36 \mathrm{cmol}_{\mathrm{c}} \mathrm{kg}^{-1} ; \mathrm{Mg}^{2+}, 0.80 \mathrm{cmol}_{\mathrm{c}} \mathrm{kg}^{-1} ; \mathrm{K}^{+}, 71 \mathrm{mg} \mathrm{kg}{ }^{-1}$; $\mathrm{P}, 49 \mathrm{mg} \mathrm{kg}^{-1}$. Cowpea [Vigna unguiculata L. (Walp.)] cv. Mauá seeds were surface-disinfected, according to Vincent (1970), and submitted to the inoculation with polymer-based and peat-based inoculant formulations. A $10 \%$ sterile sucrose solution was used as a sticking agent for the peat-based inoculant. The experiment was set up in a randomized block design, with four replicates, and eight treatments: six polymer-based inoculant formulations, one peat-based formulation, and one control without inoculation, or mineral $\mathrm{N}$. The plants received water without limitation and were harvested 50 days after the emergence (DAE). The parameters measured were nodule number, shoot dry matter and total $\mathrm{N}$ of shoot dry matter. The data were also analyzed using the Sisvar software. The variance analysis was performed, and the means were compared by the Student-Newman-Keuls test, at $5 \%$ probability.

\section{Results and Discussion}

The uncompatibilized CMC/starch blends (M3, M4 and M5) were able to sustain rhizobia cells, with nonsignificant differences in cell numbers at the beginning and at the end of the storage period (Table 1). Similar results were observed for M3 and M5 blends compatibilized with $1 \% \mathrm{ZnO}$, and for $\mathrm{M} 1, \mathrm{M} 2$, $\mathrm{M} 3$, and $\mathrm{M} 5$ with $1.5 \% \mathrm{ZnO}$. The cell number of all compositions compatibilized with $2.5 \% \mathrm{ZnO}$ decreased on the $30^{\text {th }} \mathrm{DAI}$, wich is a suggestion that $\mathrm{ZnO}$ at high concentrations may have a toxic effect on rhizobia cells. The better blends compatibilized with $\mathrm{MgO}$ were $\mathrm{M} 2$, M3, M4 and M5 with $1 \%$, and M1 and M4 with $1.5 \%$ (Table 2). The possible toxic effects of $\mathrm{ZnO}$ observed at $2.5 \%$ were also observed for $\mathrm{MgO}$.

Table 1. Survival of rhizobia incubated in polymer blends noncompatibilized or compatibilized with $\mathrm{ZnO}$, stored at room temperature $\left(20-26^{\circ} \mathrm{C}\right)$, after 1 and 30 days of inoculation $(\mathrm{DAI})^{(1)}$.

\begin{tabular}{|c|c|c|c|}
\hline \multirow[t]{2}{*}{ Carrier } & \multicolumn{2}{|c|}{ Survival $\left[\log \left(\mathrm{cfu} \mathrm{mL}^{-1}\right)\right]$} & \multirow{2}{*}{$\begin{array}{l}\text { Coefficient of } \\
\text { variation }(\%)\end{array}$} \\
\hline & $01 \mathrm{DAI}^{(1)}$ & $30 \mathrm{DAI}$ & \\
\hline & \multicolumn{3}{|c|}{ Noncompatibilized } \\
\hline M1 & $9.92 \mathrm{aA}$ & $4.85 \mathrm{cB}$ & 7.8 \\
\hline M2 & $9.96 \mathrm{aA}$ & $8.51 \mathrm{aB}$ & 5.8 \\
\hline M3 & $9.50 \mathrm{aA}$ & $8.80 \mathrm{aA}$ & 6.7 \\
\hline M4 & $10.07 \mathrm{aA}$ & $8.67 \mathrm{aA}$ & 7.3 \\
\hline \multirow[t]{2}{*}{ M5 } & $9.32 \mathrm{aA}$ & $8.21 \mathrm{aA}$ & 6.9 \\
\hline & \multicolumn{3}{|c|}{ Compatibilized $(1 \% \mathrm{ZnO})$} \\
\hline M1 & $9.51 \mathrm{aA}$ & $5.65 \mathrm{bB}$ & 9.2 \\
\hline M2 & $9.65 \mathrm{aA}$ & $7.83 \mathrm{bB}$ & 6.7 \\
\hline M3 & $9.38 \mathrm{aA}$ & $6.99 \mathrm{bA}$ & 9.6 \\
\hline M4 & $9.50 \mathrm{aA}$ & $7.89 \mathrm{bB}$ & 8.9 \\
\hline \multirow[t]{2}{*}{ M5 } & $9.23 \mathrm{aA}$ & $7.66 \mathrm{bA}$ & 6.2 \\
\hline & \multicolumn{3}{|c|}{ Compatibilized $(1.5 \% \mathrm{ZnO})$} \\
\hline M1 & $9.91 \mathrm{aA}$ & $7.11 \mathrm{bA}$ & 10.2 \\
\hline M2 & $9.34 \mathrm{aA}$ & $6.92 \mathrm{bA}$ & 10.3 \\
\hline M3 & $9.92 \mathrm{aA}$ & $4.77 \mathrm{cA}$ & 11.4 \\
\hline M4 & $9.29 \mathrm{aA}$ & $7.50 \mathrm{bB}$ & 5.3 \\
\hline \multirow[t]{2}{*}{ M5 } & $9.49 \mathrm{aA}$ & $6.49 \mathrm{cA}$ & 8.2 \\
\hline & \multicolumn{3}{|c|}{ Compatibilized $(2.5 \% \mathrm{ZnO})$} \\
\hline M1 & $9.29 \mathrm{aA}$ & $5.97 \mathrm{cB}$ & 9.4 \\
\hline M2 & $9.43 \mathrm{aA}$ & $4.89 \mathrm{cB}$ & 8.9 \\
\hline M3 & $9.44 \mathrm{aA}$ & $5.58 \mathrm{cB}$ & 8.7 \\
\hline M4 & $9.21 \mathrm{aA}$ & $5.56 \mathrm{cB}$ & 11.5 \\
\hline M5 & $9.41 \mathrm{aA}$ & $6.47 \mathrm{cB}$ & 10.6 \\
\hline
\end{tabular}

${ }^{(1)}$ Means followed by equal letters, lower case in columns an upper case in rows, did not differ by the Scott-Knott test, at $5 \%$ of probability. 
A comparison of the different blends, in the $30^{\text {th }}$ DAI, indicates the blends M3, M4 and M5 as superior. The pure CMC/starch blends M3, M4 and M5, sustained high cell concentrations (Table 1). The composition M1 was unable to sustain high bacterial cell concentrations with neither compatibilizing agents $(\mathrm{ZnO}$ or $\mathrm{MgO})$.

The CMC increases the gel viscosity, and this rheological feature may be important to make carriers suitable to maintain the rhizobial cells. The intrinsic viscosity values of the selected blends M3 and M4 are similar (Rohr, 2007).

The maintenance of the rhizobial cell concentrations throughout the beginning of the storage period, or in the maturation period, is important because both are adaptative periods of bacterial cells to the new environment, the carrier that presents different characteristics from those found in the culture media where bacterial cells reproduced previously (Hungria et al., 2005). The maintenance of initial concentrations of Bradyrhizobium cells in inoculant formulations with alternative carrier materials depends on their chemical and

Table 2. Survival of rhizobia incubated in polymer blends noncompatibilized or compatibilized with $\mathrm{MgO}$, stored at room temperature $\left(20-26^{\circ} \mathrm{C}\right)$, after 1 and 30 days of inoculation (DAI) ${ }^{(1)}$.

\begin{tabular}{|c|c|c|c|}
\hline \multirow[t]{2}{*}{ Carrier } & \multicolumn{2}{|c|}{ Survival [log $\left.\left(\mathrm{cfu} \mathrm{mL}^{-1}\right)\right]$} & \multirow{2}{*}{$\begin{array}{r}\text { Coefficient of } \\
\text { variation }(\%)\end{array}$} \\
\hline & $01 \mathrm{DAI}^{(1)}$ & $30 \mathrm{DAI}$ & \\
\hline & \multicolumn{3}{|c|}{ Noncompatibilized } \\
\hline M1 & $9.13 \mathrm{aA}$ & $4.86 \mathrm{cB}$ & 10.2 \\
\hline M2 & $8.32 \mathrm{aA}$ & $5.09 \mathrm{cA}$ & 11.5 \\
\hline M3 & $8.55 \mathrm{aA}$ & $8.71 \mathrm{aA}$ & 7.0 \\
\hline M4 & $9.11 \mathrm{aA}$ & $9.24 \mathrm{aA}$ & 6.6 \\
\hline \multirow[t]{2}{*}{ M5 } & $8.34 \mathrm{aA}$ & $6.02 \mathrm{cA}$ & 13.1 \\
\hline & \multicolumn{3}{|c|}{ Compatibilized $(1 \% \mathrm{MgO})$} \\
\hline M1 & $8.51 \mathrm{aA}$ & $6.51 \mathrm{cB}$ & 9.6 \\
\hline M2 & $8.63 \mathrm{aA}$ & $7.35 \mathrm{bA}$ & 15.0 \\
\hline M3 & $8.55 \mathrm{aA}$ & $7.30 \mathrm{bA}$ & 17.4 \\
\hline M4 & $8.19 \mathrm{aA}$ & $6.78 \mathrm{bA}$ & 13.5 \\
\hline \multirow[t]{2}{*}{ M5 } & $8.17 \mathrm{aA}$ & $6.97 \mathrm{bA}$ & 14.5 \\
\hline & \multicolumn{3}{|c|}{ Compatibilized $(1.5 \% \mathrm{MgO})$} \\
\hline M1 & $8.42 \mathrm{aA}$ & $5.43 \mathrm{cA}$ & 14.5 \\
\hline M2 & $8.42 \mathrm{aA}$ & $5.62 \mathrm{cB}$ & 14.4 \\
\hline M3 & $8.78 \mathrm{aA}$ & $5.91 \mathrm{cB}$ & 11.5 \\
\hline M4 & $8.42 \mathrm{aA}$ & $7.03 \mathrm{bA}$ & 12.5 \\
\hline \multirow[t]{2}{*}{ M5 } & $8.57 \mathrm{aA}$ & $5.79 \mathrm{cB}$ & 17.5 \\
\hline & \multicolumn{3}{|c|}{ Compatibilized $(2.5 \% \mathrm{MgO})$} \\
\hline M1 & - & - & - \\
\hline M2 & $8.57 \mathrm{aA}$ & $5.37 \mathrm{cB}$ & 11.2 \\
\hline M3 & $8.42 \mathrm{aA}$ & $6.08 \mathrm{cB}$ & 7.2 \\
\hline M4 & $8.64 \mathrm{aA}$ & $5.23 \mathrm{cB}$ & 7.1 \\
\hline M5 & $8.66 \mathrm{aA}$ & $5.66 \mathrm{cB}$ & 17.7 \\
\hline
\end{tabular}

physical characteristics (Figueiredo et al, 1992; Khavazi et al., 2007).

In the experiment for evaluating the survival of rhizobia cells, during 165 days of storage, the rhizobial cell concentration did not present high variations in the initial periods of storage. The compositions M4 and M3 with $1 \% \mathrm{MgO}$ were able to maintain the same concentration of rhizobia cells throughout the storage period, while the peat formulation presented a slightly higher decrease (Figure 1). CMC/starch blends compatibilized with $\mathrm{MgO}$ are compatible with the standards determined by the Brazilian law, regarding inoculant cell concentration (up to $10^{9}$ cells per gram or milliliter of inoculant) and shelf life (at least six months) (Brasil, 2004). Denardin \& Freire (2000) showed that blends of natural or synthetic polymers are able to maintain high concentrations of viable rhizobial cells for over six months. The angular coefficient of linear regressions for the inoculants developed with the polymer blends compatibilized with $1 \% \mathrm{MgO}$ was slightly negative. The angular coefficients of the other five inoculant formulations, including peat inoculant, were lower. The survival reduction of rhizobial cells in polymer formulations compatibilized with $\mathrm{ZnO}$ was of five (M4) or six (M3) units, while in peat-based inoculant it was of one unit. These results showed the importance of the use of an appropriate compatibilizing agent to maintain rhizobial cells viability for longer periods.

To develop useful polymeric materials, it is important to choose more adapted compatibilizing agents. The specific antimicrobial activity of zinc and magnesium oxides against some groups has already been reported, e.g., $\mathrm{ZnO}$ at low concentrations is highly toxic to Staphylococcus (Sawai, 2003; Sawai et al., 2007) but not to Escherichia coli (Sawai, 2003). However, both genera were affected by $\mathrm{MgO}$ at low concentrations (Sawai, 2003). Another study showed that Bacillus spp. and Pseudomonas spp. soil bacteria were able to solubilize $\mathrm{ZnO}$ and other zinc minerals in culture media, without any sign of toxicity (Saravanan at al., 2004).

At high $\mathrm{ZnO}$ concentrations, some of the oxide molecules are possibly no longer complexed to the polymeric bonds, where they act as a compatibilizing agent, but instead, the exceeding amount might become bioavailable to bacterial cells and cause a harmful effect. At such high concentrations, conductivimetric measurements are needed to evaluate the amount of noncomplexed $\mathrm{ZnO}$ to the $\mathrm{CMC} /$ starch system. 
Other zinc forms, such as zinc salts have been reported to affect the development of some rhizobia genera in culture media (Matsuda et al., 2002). That study showed that Bradyrhizobium strains were less affected than strains of Rhizobium, Mesorhizobium, Sinorhizobium and Azorhizobium. These results confirm the need to understand the effect of different zinc forms on rhizobial growth.

The capacity of rhizobial cells to survive in $\mathrm{MgO}$ compatibilized polymer blends is likely due to the bacterial compatibility with this oxide. Shoot development parameters in the greenhouse experiment were similar, and the analysis of the nodulation parameters showed that the inoculant formulations were able to provide the same nodulation in polymer blend-based and peat-based inoculants (Table 3). No differences were observed in the $\mathrm{N}$ content of shoot. Other studies on the efficiency of alternative carriers (such as cellulose, sawdust and cork residues) showed similar results (Jawson et al., 1989; Kostov \& Lynch, 1998; Ferreira \& Castro, 2005; Albareda et al., 2008). In sterile
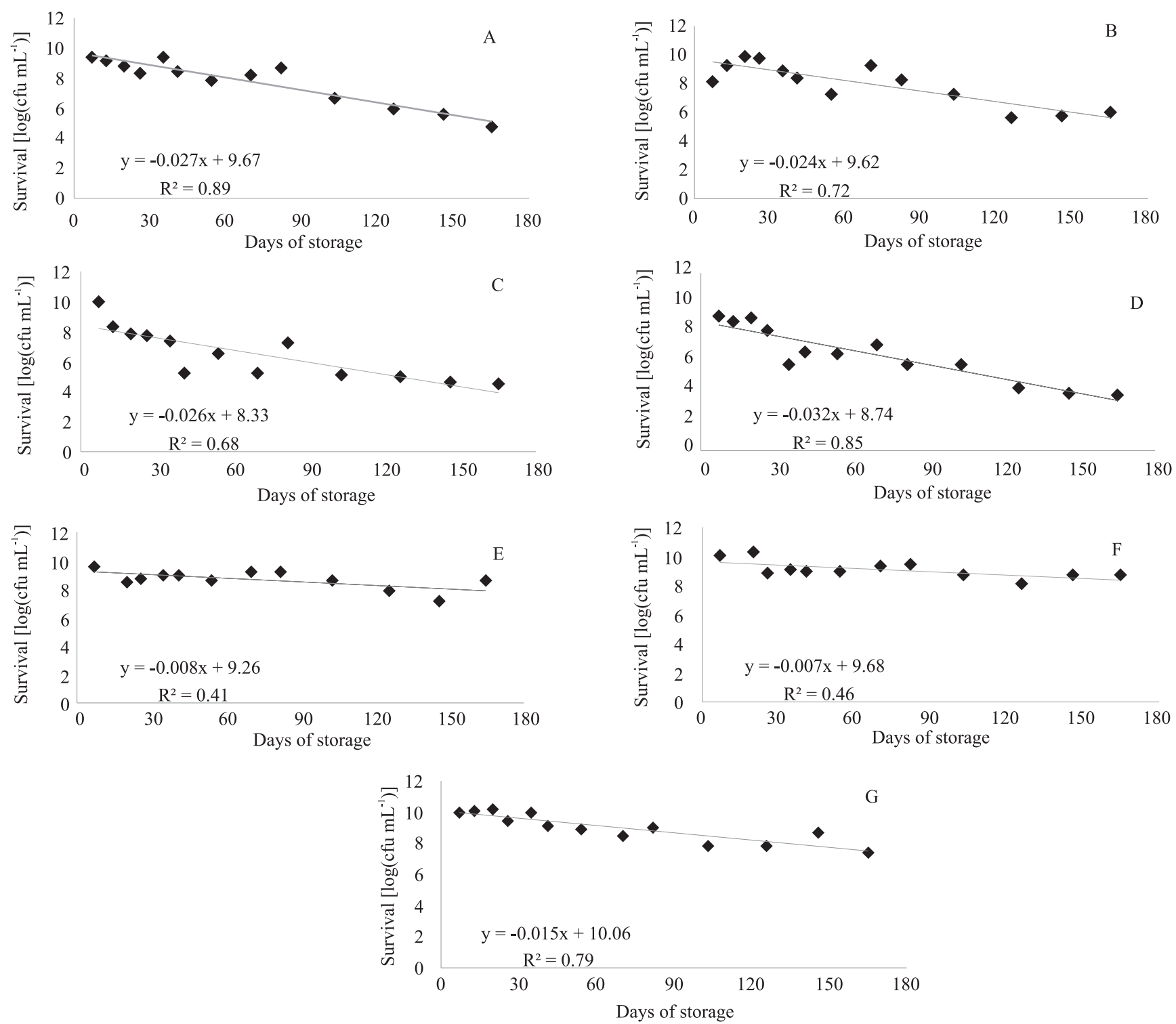

Figure 1. Survival of B. japonicum, BR 3267 strain, in inoculant formulations with polymer blends M3 and M4, noncompatibilized (A and $\mathrm{B}$ respectively), or compatibilized with $1 \% \mathrm{ZnO}$ (C and $\mathrm{D}$ respectively), or with $1 \% \mathrm{MgO}$ ( $\mathrm{E}$ and $\mathrm{F}$ respectively), and peat $(\mathrm{G})$. Each point represents the mean of three replicates. All linear equation coefficients were statistically significant, at $5 \%$ probability. 
Table 3. Shoot dry weight, nodule number, and shoot nitrogen content of cowpea plants with $B$. japonicum strain BR 3267 inoculation, using $\mathrm{CMC} /$ starch and peat-based inoculant formulations, 50 days after emergence ${ }^{(1)}$.

\begin{tabular}{lccc}
\hline Carrier & $\begin{array}{c}\text { Shoot dry matter } \\
\text { (g per plant) }\end{array}$ & $\begin{array}{c}\text { Nodule } \\
\text { per plant }\end{array}$ & $\begin{array}{c}\text { Shoot nitrogen } \\
\text { content (mg per plant) }\end{array}$ \\
\hline M3 & $3.38 \mathrm{a}$ & $94 \mathrm{a}$ & $67.97 \mathrm{a}$ \\
M4 & $3.92 \mathrm{a}$ & $102 \mathrm{a}$ & $93.40 \mathrm{a}$ \\
$\mathrm{M} 3+\mathrm{ZnO}(1 \%)$ & $3.65 \mathrm{a}$ & $104 \mathrm{a}$ & $92.22 \mathrm{a}$ \\
$\mathrm{M} 4+\mathrm{ZnO}(1 \%)$ & $3.86 \mathrm{a}$ & $91 \mathrm{a}$ & $97.74 \mathrm{a}$ \\
$\mathrm{M} 3+\mathrm{MgO}(1 \%)$ & $3.87 \mathrm{a}$ & $77 \mathrm{a}$ & $92.05 \mathrm{a}$ \\
M4+MgO (1\%) & $3.30 \mathrm{a}$ & $95 \mathrm{a}$ & $66.00 \mathrm{a}$ \\
Peat & $2.98 \mathrm{a}$ & $78 \mathrm{a}$ & $78.79 \mathrm{a}$ \\
Control & $2.91 \mathrm{a}$ & $44 \mathrm{~b}$ & $65.82 \mathrm{a}$ \\
\hline CV $(\%)$ & 23.9 & 19.6 & 32.8 \\
\hline
\end{tabular}

(1)Means followed by equal letters did not differ by the Student-NewmanKeuls test, at $5 \%$ of probability.

conditions, blends of jataí, xanthan gums and PVP also resulted in abundant soybean nodulation, as observed in peat-based inoculants (Denardin, 1997).

\section{Conclusions}

1. Polymer blend composition and concentration of compatibilizing agent have effect on the maintenance of rhizobial viability after storage.

2 . The use of polymer blends compatibilized with an appropriate compatibilizing agent can extend rhizobial survival.

3. Peat or polymer-based inoculants provide similar rhyzobium nodulation efficiencies.

\section{References}

ALBAREDA, M.; RODRIGUEZ-NAVARRO, D.N.; CAMACHO, M.; TEMPRANO, F.J. Alternatives to peat as a carrier for rhizobia inoculants: solid and liquid formulations. Soil Biology and Biochemistry, v.40, p.2771-2779, 2008.

BASHAN, Y.; GONZALES, L.E. Long-term survival of the plant-growth-promoting bacteria Azospirillum brasilense and Pseudomonas fluorescens in dry alginate inoculant. Applied Microbiology and Biotechnology, v.51, p.262-266, 1999.

BEN REBAH, F.; PRÉVOST, D.; YEZZA, A.; TYAGI, R.D. Agro-industrial waste materials and wastewater sludge for rhizobial inoculant production: a review. Bioresource Technology, v.98, p.3535-3546, 2007.

BRASIL. Ministério da Agricultura, Pecuária e Abastecimento. Instrução Normativa $n^{\circ}$, de 06 de agosto de 2004. Aprova as definições e normas sobre especificações, garantias, registro, embalagem e rotulagem dos inoculantes destinados à agricultura, bem como a relação dos microrganismos autorizados para produção de inoculantes no Brasil. Diário Oficial [da] República Federativa do Brasil, 10 ago. 2004. Seção 1, p.17.

CLAESSEN, M.C.E. (Org.). Manual de métodos de análise de solo. 2.ed. rev. atual. Rio de Janeiro: Embrapa-CNPS, 1997. 212p. (Embrapa-CNPS. Documentos, 1).

DEAKER, R.; ROUGHLEY, R.J.; KENNEDY, I.R. Desiccation tolerance of rhizobia when protected by synthetic polymers. Soil Biology and Biochemistry, v.39, p.573-580, 2007.

DENARDIN, N.D. Avaliação de polímeros para formulação de inoculantes com Bradyrhizobium elkanii. 1997. 87p. Tese (Doutorado) - Universidade Federal do Rio Grande do Sul, Porto Alegre.

DENARDIN, N.D.; FREIRE, J.R.J. Assessment of polymers for the formulation of legume inoculants. World Journal of Microbiology and Biotechnology, v.16, p.215-217, 2000.

DOMMERGUES, Y.R.; DIEM, H.G.; DIVIES, C. Polyacrylamide-entrapped Rhizobium as an inoculant for legumes. Applied and Environmental Microbiology, v.37, p.779-781, 1979.

FERREIRA, E.M.; CASTRO, I.V. e. Residues of the cork industry as carriers for the production of legume inoculants. Silva Lusitana, v.13, p.159-167, 2005.

FIGUEIREDO, M. do V.B.; STAMFORD, N.P.; VIDOR, C.; VILAR, J.J.; OLIVEIRA FILHO, E.C. de. Sobrevivência do Bradyrhizobium sp. em substratos alternativos. Pesquisa Agropecuária Brasileira, v.27, p.1497-1506, 1992.

FREIRE, J.R.J.; VERNETTI, F. de J. A pesquisa com soja, a seleção de rizóbio e produção de inoculantes no Brasil. Pesquisa Agropecuária Gaúcha, v.5, p.117-126, 1999.

HARA, F.A. dos S.; OLIVEIRA, L.A. Características fisiológicas e ecológicas de isolados de rizóbios oriundos de solos ácidos de Iranduba, Amazonas. Pesquisa Agropecuária Brasileira, v.40, p.667-672, 2005.

HUNGRIA, M.; LOUREIRO, M.F.; MENDES, I.C.; CAMPO, R.J.; GRAHAM, P.H. Inoculant preparation, production and application. In: WERNER, D.; NEWTON, W.E. (Ed.). Nitrogen fixation in agriculture, forestry, ecology, and the environment. Dordrecht: Springer, 2005. p.223-253.

JAWSON, M.D.; FRANZLUBBERS, A.J.; BERG, R.K. Bradyrhizobium japonicum survival in and soybean inoculation with fluid gels. Applied and Environmental Microbiology, v.55, p.617-622, 1989.

KHAVAZI, K.; REJALI, F.; SEGUIN, P.; MIRANSARI, M. Effects of carrier, sterilization method and incubation on survival of Bradyrhizobium japonicum in soybean (Glycine max L.) inoculants. Enzyme and Microbial Technology, v.41, p.780-784, 2007.

KOSTOV, O.; LYNCH, L.M. Composted sawdust as a carrier for Bradyrhizobium, Rhizobium and Azospirillum in crop inoculation. World Journal of Microbiology and Biotechnology, v.14, p.389-397, 1998. 
LUPWAYI, N.Z.; CLAYTON, G.W.; RICE, W.A. Rhizobial inoculants for legume crops. Journal of Crop Improvement, v.15, p.289-321, 2006.

MARTINS, L.M.V.; XAVIER, G.R.; RANGEL, F.W.; RIBEIRO, J.R.A.; NEVES, M.C.P.; MORGADO, L.B.; RUMJANEK, N.G. Contribution of biological nitrogen fixation to cowpea: a strategy for improving grain yield in the Semi-Arid region of Brazil. Biology and Fertility of Soils, v.38, p.333-339, 2003.

MATSUDA, A.; MOREIRA, F.M. de S.; SIQUEIRA, J.O. Tolerância de rizóbios de diferentes procedências ao zinco, cobre e cádmio. Pesquisa Agropecuária Brasileira, v.37, p.343-355, 2002.

MILES, A.A.; MISRA, S.S. The estimation of the bacterial power of the blood. Journal of Hygiene, v.38, p.732-749, 1938.

PARKER R.; RING S.G. Aspects of the physical chemistry of starch. Journal of Cereal Science, v.34, p.1-17, 2001.

ROHR, T.G. Estudo reológico da mistura carboximetilcelulose/ amido e sua utilização como veículo de inoculação bacteriano. 2007. 98p. Dissertação (Mestrado) - Universidade Federal Rural do Rio de Janeiro, Seropédica.

SANZ, T.; FERNÁNDEZ, M.A.; SALVADOR, A.; MUÑHOZ, J.; FISZMAN, S.M. Thermogelation properties of methylcellulose (MC) and their effect on a batter formula. Food Hydrocolloids, V.19, p.141-147, 2005.

SARAVANAN, V.S.; SUBRAMONIAM, S.R.; RAJ, S.A. Assessing in vitro volatilization potential of different zinc solubilizing bacterial (ZSB) isolates. Brazilian Journal of Microbiology, v.35, p.121-125, 2004.

SARR, A.; DIOP, B.; PELTIER, R.; NEYRA, M.; LESUEUR, D. Effect of rhizobial inoculation methods and host plant provenances on nodulation and growth of Acacia senegal and Acacia nilotica. New Forests, v.29, p.75-87, 2005.

SAWAI, J. Quantitative evaluation of antibacterial activities of metallic oxide powders $(\mathrm{ZnO}, \mathrm{MgO}$ and $\mathrm{CaO})$ by conductimetric assay. Journal of Microbiological Methods, v.54, p.177-182, 2003.

SAWAI, J.; YAMAMOTO, O.; ÖZKAL, B.; NAKAGAWA, Z.E. Antibacterial activity of carbon-coated zinc oxide particles. Biocontrol Science, v.12, p.15-20, 2007.

SCHUH, C.A. Biopolímeros como suporte para inoculantes. 2005. 81p. Dissertação (Mestrado) - Universidade Federal do Rio Grande do Sul, Porto Alegre.

SUVOROVA, A.I.; TJUKOVA, I.S.; TRUFANOVA, E.I. Thermodynamic and diffusion properties of biodegradable systems based on starch and cellulose derivatives. Journal of Polymers and the Environment, v.7, p.35-40, 1999.

VINCENT, J.M. A manual for the practical study of root nodule-bacteria. Oxford: Blackwell Scientific, 1970. 164p. (International Biological Programme Handbook, 15).

Received on January 15, 2009 and accepted on August 10, 2009 